\title{
ARTIKKELIT
}

\section{У Koettu terveys, elintavat ja fyysinen toimintakyky - vuosina 1920 ja 1940 syntyneiden kohorttien vertailu}

\author{
Riitta Henriksson ${ }^{1}$, Marika Salminen $^{1,2}$, Seija Arve ${ }^{1}$, Matti Viitanen $^{3}$, Sini Eloranta $^{1}$ \\ Turun yliopisto, Hoitotieteen laitos ${ }^{1}$, Turun yliopisto, Yleisläaketiede ${ }^{2}$,Turun kaupunki, Hyvinvointitoimiala; \\ Turun yliopisto, Lääketieteellinen tiedekunta ${ }^{3}$, Turun ammattikorkeakoulu, Terveys ja hyvinvointi;
}

\begin{abstract}
Tutkimuksen tarkoituksena oli vertailla vuosina 1920 (n=1032) ja 1940 ( $n=956)$ syntyneiden 70-vuotiaiden kotona asuvien turkulaisten koettua terveyttä, elintapoja ja fyysistä toimintakykyä. Tiedot koetusta terveydestä, elintavoista (tupakointi, alkoholinkäyttö ja painoindeksi) ja fyysisestä toimintakyvystä (päivittäiset toiminnot, välineelliset toiminnot ja päivittäisiä toimintoja haittaavat oireet) kerättiin kyselylomakkeiden ja haastatteluiden avulla. Tulosten mukaan vuonna 1940 syntyneet kokivat terveytensä ja fyysisen toimintakykynsä paremmiksi kuin vuonna 1920 syntyneet. Lisäksi 1940 syntyneillä oli vähemmän päivittäistä toimintaa haittaavia oireita kuin vuonna 1920 syntyneillä. Alkoholin käyttö ja ylipaino sen sijaan olivat yleisempiä 1940 syntyneiden kuin 1920 syntyneiden keskuudessa. Tulokset ovat tärkeitä suunniteltaessa ennaltaehkäiseviä palveluita ikääntyville.
\end{abstract}

\section{Johdanto}

Suomalainen väestö ikääntyy ja elinajanodote nousee (Tilastokeskus 2016; WHO 2016). Tärkeä kysymys yhteiskunta-, sosiaali- ja terveyspolitiikan sekä ikäihmisten palveluiden suunnittelemisen kannalta on, kehittyykö ikäihmisten terveys ja toimintakyky suotuisaan suuntaan.

Koettu terveys kuvaa terveyden subjektiivista ulottuvuutta, ja sen merkitys on gerontologisessa tutkimuksessa tunnustettu, ja sen on havaittu olevan hyvä terveydentilan mittari (Heikkinen 2013; Whitley, Popham \&
Benzeval 2016). Ikäihmisten koettu terveys on aikaisempien tutkimusten perusteella kohentunut vuosien saatossa (Leinonen, Suominen, Sakari-Rantala, Laukkanen \& Heikkinen 2006; Leskinen ym. 2010; Galenkamp, Braam, Huisman \& Deeg 2012; Helldán \& Helakorpi 2014; Johansson, Midlöv \& Sundquist 2015; Giron 2016). On havaittu, että suomalaisten ikäihmisten koettu terveys on parantunut tasaisesti 1990-luvun alusta alkaen (Helldán \& Helakorpi 2014).

Aikaisemmat tutkimukset ovat osoittaneet, että tupakointi on vähentynyt iäkkäiden miesten keskuudessa, kun taas iäkkäiden 
naisten tupakointi on jopa hieman yleistynyt (Jiménez Trujillo ym. 2010; Martin, Schoeni, Andreski \& Jagger 2012; Helldán \& Helakorpi 2014). Tupakoivia naisia on kuitenkin edelleen suhteellisesti vähemmän kuin miehiä (Jiménez Trujillo ym. 2010; Helldán \& Helakorpi 2014). Ruotsalaisessa tutkimuksessa havaittiin, että 1970-luvulta 1990-luvulle tultaessa tupakoivien miesten määrä väheni lähes 50 \%:sta $21 \%$ :iin (Kumar Dey, Rothenberg, Sundh, Bosaeus \& Steen 2001). Espanjassa 1990-luvun puolivälissä naisista tupakoi $2 \%$ ja 2000-luvun alussa $3 \%$, vastaavat osuudet miehillä olivat noin $25 \%$ ja $15 \%$ (Jiménez Trujillo ym. 2010).

Ikäihmisten alkoholinkäyttö on lisääntynyt ajan kuluessa (Pérés, Helmer, Letenneur, Jacqmin-Gadda \& Barberger-Gateau 2005; Ahacic, Kennison \& Thorslund 2011; Helldán \& Helakorpi 2014). Ruotsissa tehdyn tutkimuksen mukaan 70-vuotiaista naisista vanhemmassa kohortissa alkoholia ilmoitti käyttävänsä $12 \%$, kun nuoremmassa kohortissa vastaava osuus oli 47 \% (Cabrera ym. 2003). Samansuuntaisia tuloksia on saatu Suomessa tutkittaessa eläkeikäisen väestön terveyttä ja terveyskäyttäytymistä. Vuonna 1993 naisista $62 \%$ ja miehistä $31 \%$ ilmoitti, ettei ole käyttänyt alkoholia vuoteen. Vuonna 2013 vastaavat osuudet olivat $40 \%$ ja $23 \%$. (Helldán \& Helakorpi 2014.)

Ikäihmisten keskimääräinen paino on noussut usean tutkimuksen mukaan 197080-luvulta 2000-luvulle tultaessa (Martin ym. 2012; Karadag Caman ym. 2013; Helldán \& Helakorpi 2014; De Munter, Tynelius, Magnusson \& Rasmussen 2015). Yli 65-vuotiaiden ylipainoisten suhteellinen osuus oli 1990-luvun alussa noin 12-18\%, kun se 2010-luvun alussa oli noin $25 \%$ (Martin ym. 2012; Helldán \& Helakorpi 2014). Tutkimusten mukaan painon nousu oli suurempaa miehillä kuin naisilla (Heeb 2009; Karadag Caman ym. 2013; De Munter ym. 2015).

Tutkimustulokset ikäihmisten toimintakyvyn muutoksista ovat ristiriitaisia. Useiden tutkimusten mukaan toimintakyvyssä oli tapahtunut positiivista kehitystä (Laitalainen, Helakorpi, Martelin \& Uutela 2010; Martin ym. 2012; Falk ym. 2014; Helldán \& Helakorpi 2014; Morciano, Hancock \& Pudney 2015) tai se oli pysynyt suhteellisen samankaltaisena (Espelt ym. 2010; van Gool ym. 2011; Sjölund, Wimo, Qiu, Engström \& von Strauss 2014; Angleman, Santoni, Von Strauss \& Fratiglioni 2015), mutta joidenkin tutkimusten mukaan ikäihmisten toimintakyky oli jopa heikentynyt (Martinez-Huedo ym. 2011; PalaciosCeña ym. 2012). Göteborg H70 -kohorttitutkimuksessa osoitettiin, että 65-vuotiaiden ikäryhmässä viisi vuotta nuorempi ikäkohortti oli aikaisempaa ikäkohorttia toimintakykyisempi (Steen 2002). Ikäihmisten toimintakyvyn on osoitettu parantuneen raskaiden kotitöiden (Leinonen ym. 2006), liikkumisen ja liikuntakyvyn (Pérés ym. 2005; Jagger ym. 2007; Falk ym. 2014), peseytymisen, pukeutumisen, ruoanlaittamisen, näön (Jagger ym. 2007; Donald, Foy \& Jagger 2010; Falk ym. 2014) ja kuulon (Jagger ym. 2007) osalta. Toisaalta tutkimuksissa oli viitteitä siitä, että kuulon ja liikuntakyvyn aiheuttamat toimintakyvyn rajoitteet (Parker, Ahacic \& Thorslund 2005) sekä lievät vaikeudet esimerkiksi rappujen nousemisessa ja pukeutumisessa olisivat lisääntyneet nuoremmalla kohortilla verrattuna vanhempaan kohorttiin (van Gool ym. 2011). Päivittäistä toimintaa haittaavat oireet, kuten huimauksen ja rintakivun kokeminen, olivat sen sijaan vähentyneet nuoremmilla kohorteilla vanhempiin kohortteihin verrattuna (Pérés ym. 2005; Leinonen ym. 2006; Helldán \& Helakorpi 2014).

\section{Tutkimuksen tarkoitus}

Tutkimuksen tarkoituksena oli vertailla vuosina 1920 ja 1940 syntyneiden kotona asuvien 70-vuotiaiden koettua terveyttä, elintapoja ja fyysistä toimintakykyä. 


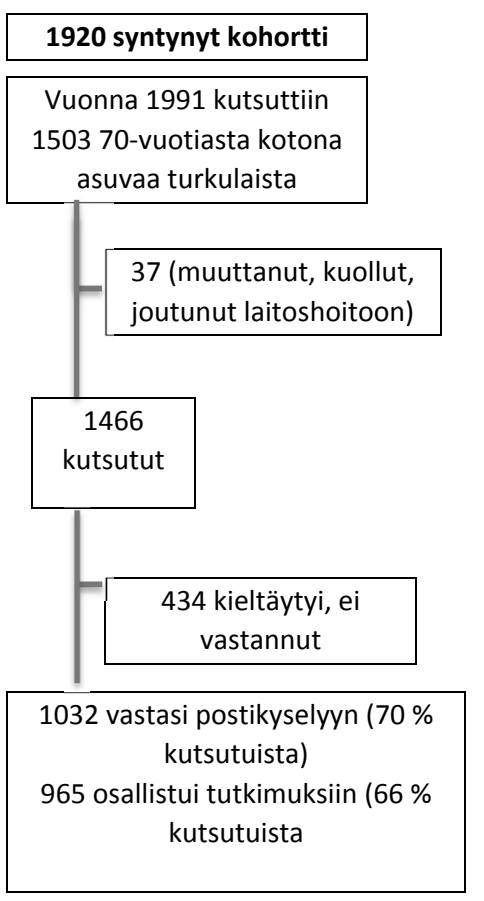

Kuvio 1. Tutkimuksen kulkukaavio.

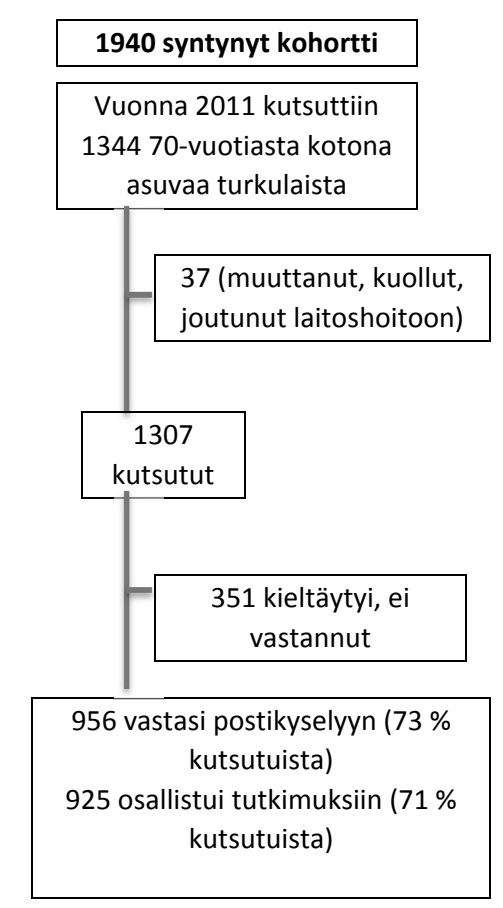

\section{Tutkimuskysymys}

Millainen oli kotona asuvien 70-vuotiaiden koettu terveys, elintavat (tupakointi, alkoholinkäyttö, painoindeksi) ja fyysinen toimintakyky (päivittäisissä ja välineellisissä toiminnoissa selviytyminen sekä toimintaa haittaavat oireet) vuosina 1920 ja 1940 syntyneillä kohorteilla?

\section{Aineisto ja menetelmät}

Tutkimus on osa Turun vanhustutkimusta (TUVA) ja uutta Turun vanhustutkimusta (UTUVA) (Lehtonen \& Tilvis 1994; Arve ym. 2012; Eloranta, Arve, Isoaho, Lehtonen \& Viitanen 2015). TUVA ja UTUVA ovat väestöpohjaisia tutkimuksia. TUVA-tutkimuksen aineisto kerättiin vuonna 1991 ja UTUVAtutkimuksen vuonna 2011. Kohdejoukkoina olivat vuonna 1920 (TUVA, $n=1032$ ) ja vuonna 1940 (UTUVA, n=956) syntyneet, kotona asu- vat turkulaiset (kuvio 1). Tutkittavat poimittiin syntymävuoden perusteella väestörekisteristä.

TUVA ja UTUVA -aineistot kerättiin postitse lähetetyillä kyselylomakkeilla, hoitajan vastaanotolla tekemillä haastatteluilla ja lääkärin kliinisillä tutkimuksilla (Lehtonen \& Tilvis 1994; Arve ym. 2012; Eloranta ym. 2015). Tässä tutkimuksessa raportoidaan osa TUVA- ja UTUVA -tutkimusten aineistoista, jotka kerättiin tutkittavilta kirjekyselyllä. Lisäksi tutkittavien paino ja pituus mitattiin tutkimushoitajan vastaanotolla.

Taustatietoina vastaajilta kysyttiin sukupuolta, siviilisäätyä, koulutusta ja aikaisemman työn fyysisyyttä. Koettua terveyttä arvioitiin tutkittavan kokemuksella omasta terveydestä (pidän itseäni terveenä, melko terveenä, sairaana, hyvin sairaana), kokemuksella omasta terveydestä suhteessa muihin samanikäisiin (parempi, suunnilleen samanlainen, huonompi) sekä kokemuksella omasta terveydestä kuluneen vuoden aikana (parantunut, 
pysynyt suunnilleen ennallaan, huonontunut) (Ocampo 2010).

Elintavoista tupakointia arvioitiin väittämillä: 1. ei ole koskaan tupakoinut, 2. on tupakoinut ja 3. tupakoi. Alkoholin käyttöä arvioitiin väittämillä: 1. ei käytä lainkaan, 2. käyttää harvemmin kuin kerran viikossa ja 3. käyttää kerran viikossa tai useammin. Pituuden ja painon avulla laskettiin tutkittavan painoindeksi. Suomessa ikääntyneiden yli 60-vuotiaiden suositeltava painoindeksi on 24-29 kg/m² (Käypä hoito -suositus 2013). Tässä tutkimuksessa painoindeksi luokiteltiin seuraavasti: alle $24 \mathrm{~kg} / \mathrm{m}^{2}$ (alipainoinen), 24-29 kg/m² (normaalipainoinen) ja yli $29 \mathrm{~kg} / \mathrm{m}^{2}$ (ylipainoinen).

Fyysistä toimintakykyä mitattiin päivittäisten toimintojen (pystyy kävelemään 500 metrin matkan, liikkumaan asunnossa, nousemaan ylös tuolista ja sängystä, nousemaan 10 porrasta, syömään, pukeutumaan, peseytymään ja käyttämään wc:tä itsenäisesti) ja välineellisten toimintojen (pystyy tekemään raskaita kotitöitä, kevyitä kotitöitä, henkilökohtaisia ostoksia, pystyy valmistamaan omat ateriansa, hoitamaan raha-asiansa, käyttämään puhelinta ja kantamaan 5 kg:n taakan) avulla (Katz 1983). TUVA-tutkimuksen osalta vastausvaihtoehdot edellä mainittujen muuttujien osalta olivat: 1. kyllä, 2. ei, 3. kykenisin tekemään, mutta muusta syystä johtuen en tee ja 4. ei tietoa. Luokat luokiteltiin uudelleen seuraavasti: 1. kyllä, 2. ei (alkuperäinen luokka 2) sekä kykenisin tekemään, mutta muusta syystä johtuen en tee (alkuperäinen luokka 3). Ei tietoa -vastaukset (alkuperäinen luokka 4) jätettiin pois analyyseistä. UTUVA-tutkimuksen osalta vastaavien muuttujien vastausvaihtoehdot olivat 1. kyllä ja 2. ei.

Toimintaa haittaavia oireita arvioitiin seuraavien muuttujien avulla: pohjekipu kävellessä, toimintaa haittaava päänsärky, toimintaa haittaava huimaus, ruokahaluttomuus, rintakipuja levossa, rintakipuja rasituksessa, hengenahdistusta levossa ja hengenahdistusta rasituksessa. Vastausvaihtoehdot olivat 1. ei, 2. toisinaan ja 3. päivittäin.
TUVA- ja UTUVA-aineistoja kuvailtiin tarkastelemalla muuttujien frekvenssi- ja prosenttijakaumia. Kohorttien välisiä eroja testattiin $\chi^{2}$-riippumattomuustestillä ja Fisherin tarkalla testillä. P-arvoa, joka oli 0,05 tai sitä pienempi, pidettiin tilastollisesti merkitsevänä. Tilastolliset analyysit tehtiin SAS 9.4 -ohjelmistolla.

\section{Tutkimuseettiset kysymykset}

Turun vanhustutkimuksella on Turun kaupungin eettisen toimikunnan ( $\$ 8 / 19.12 .1990)$ ja Varsinais-Suomen sairaanhoitopiirin eettisen toimikunnan ( $\S 31 / 16.2 .2010)$ puollot. Ensimmäiseen Turun vanhustutkimukseen (TUVA) on saatu tutkimuslupa Turun terveystoimesta ja uuteen Turun vanhustutkimukseen (UTUVA) Turun hyvinvointitoimialueelta. Tutkittavien tietoinen suostumus tutkimukseen osallistumisesta kysyttiin kirjallisesti sekä TUVA- että UTUVA-tutkimuksen ensimmäisen kirjekyselyn yhteydessä. Tutkittavia informoitiin myös kirjallisesti tutkimuksesta, sen tarkoituksesta ja tutkittavien oikeuksista. Tutkittavilla oli mahdollisuus keskeyttää osallistuminen tutkimuksen missä tahansa vaiheessa. (TENK 2012.)

\section{Tulokset}

\section{Vastaajien taustatiedot}

Vuonna 1940 syntyneiden keskuudessa oli vähemmän leskeksi jääneitä ja yksin asuvia $(\mathrm{p}<0.001)$, heillä oli korkeampi koulutustaso $(p<0.001)$, ja he olivat useammin tehneet ei-fyysistä työtä ( $p<0.001)$ vuonna 1920 syntyneisiin verrattuna (taulukko 1 ).

\section{Koettu terveys}

Vuonna 1940 syntyneet kokivat koetun terveytensä paremmaksi kuin vuonna 1920 syntyneet (p<0.001) (taulukko 2). Vuonna 1940 synty- 
Taulukko 1. Vuonna $1920(n=1032)$ ja $1940(n=956)$ syntyneiden 70-vuotiaiden taustatiedot (\%).

\begin{tabular}{lccc}
\hline & $\begin{array}{c}\text { v. } 1920 \\
\text { syntyneet \% }\end{array}$ & $\begin{array}{c}\text { v. 1940 } \\
\text { syntyneet \% }\end{array}$ & p-arvo \\
\hline Sukupuoli & 36 & 41 & \\
Mies & 64 & 59 & 0.029 \\
Nainen & & & \\
Siviilisääty & 53 & 64 & \\
Naimisissa tai asuu jonkun kanssa & 16 & 22 & $<0.001$ \\
Asuu yksin tai eronnut & 31 & 13 & \\
Leski & 19 & 45 & $<0.001$ \\
Koulutus & 81 & 55 & \\
Koulutus keskimääräistä korkeampi* & & & \\
Koulutus keskimääräinen tai alempi & 40 & 83 & $<0.001$ \\
Aikaisempi työ & 60 & 17 & \\
Fyysinen & & & \\
Ei-fyysinen & &
\end{tabular}

$*_{4-8 \text {-vuotinen kansa- tai peruskoulu }}$

Taulukko 2. Vuonna 1920 ( $n=1032)$ ja $1940(n=956)$ syntyneiden 70-vuotiaiden koettu terveys (\%).

\begin{tabular}{lccc}
\hline & $\begin{array}{c}\text { v. } 1920 \\
\text { syntyneet \% }\end{array}$ & $\begin{array}{c}\text { v. 1940 } \\
\text { syntyneet \% }\end{array}$ & p-arvo \\
\hline Itse arvioitu terveydentila & 74 & 88 & \\
Terve tai melko terve & 26 & 12 & $<0.001$ \\
Sairas tai hyvin sairas & & & \\
Terveydentila samanikäisiin verrattuna & 16 & 19 & \\
Parempi & 56 & 74 & $<0.001$ \\
Samanlainen & 28 & 7 & \\
Huonompi & & & \\
Terveydentila viimeksi kuluneen vuoden aikana & 2 & 4 & $<0.001$ \\
Parantunut & 77 & 81 & \\
Pysynyt suunnilleen ennallaan & 21 & 15 & \\
Huonontunut & &
\end{tabular}

neistä itsensä terveeksi koki lähes joka viides, kun vuonna 1920 syntyneistä vain joka kymmenes koki itsensä terveeksi. Itsensä sairaaksi tai hyvin sairaaksi kokeneiden osuus oli 14 prosenttiyksikköä alhaisempi 1940 syntyneiden kohortissa kuin vuonna 1920 syntyneiden kohortissa.

\section{Elintavat}

Tupakoinnin suhteen kohorttien välillä ei ollut tilastollisesti merkitsevää eroa. Täysin raittiiden 70-vuotiaiden osuus oli vähentynyt kah- denkymmenen vuoden aikana (taulukko 3). Vuonna 1940 syntyneistä $17 \%$ ilmoitti, ettei käytä lainkaan alkoholia, kun vuonna 1920 syntyneistä samoin ilmoitti $40 \%(\mathrm{p}<0.001)$. Kerran viikossa tai useammin alkoholia käytti 1940 syntyneiden kohortissa useampi kuin joka kolmas, kun vuonna 1920 syntyneiden kohortissa alkoholia kerran viikossa tai useammin käytti vain noin joka kymmenes ( $\mathrm{p}<0.001)$.

Lähes puolet 70-vuotiaista oli normaalipainoisia molemmissa kohorteissa. Ylipainoisten osuus oli noussut: vuonna 1940 syntyneistä noin joka kolmannen ja vuonna 1920 syn- 
Taulukko 3. Vuonna $1920(n=1032)$ ja $1940(n=956)$ syntyneiden 70-vuotiaiden elintavat (\%).

\begin{tabular}{lccc}
\hline & $\begin{array}{c}\text { v. } \mathbf{1 9 2 0} \\
\text { syntyneet \% }\end{array}$ & $\begin{array}{c}\text { v. } \mathbf{1 9 4 0} \\
\text { syntyneet \% }\end{array}$ & p-arvo \\
\hline Tupakointi & 57 & 56 & $0.82 \mathrm{x}$ \\
Ei koskaan tupakoinut & 32 & 32 & \\
Tupakoinut & 11 & 12 & \\
Tupakoi & & & \\
Alkoholinkäyttö & 38 & 17 & $<0.001$ \\
Ei käytä lainkaan & 50 & 53 & \\
Käyttää harvemmin kuin kerran viikossa & 12 & 30 & \\
Käyttää kerran viikossa tai useammin & & & \\
Painoindeksi & 26 & 19 & $<0.001$ \\
alle $24 \mathrm{~kg} / \mathrm{m}^{2}$ & 52 & 47 & \\
$24-29 \mathrm{~kg} / \mathrm{m}^{2}$ & 22 & 34 & \\
yli $29 \mathrm{~kg} / \mathrm{m}^{2}$ & & & \\
\hline
\end{tabular}

Taulukko 4. Vuonna $1920(n=1032)$ ja $1940(n=956)$ syntyneiden 70-vuotiaiden päivittäis- ja välineellisistä toiminnoista selviytyminen (\%).

\begin{tabular}{lccc}
\hline & $\begin{array}{c}\text { V. 1920 } \\
\text { syntyneet \% }\end{array}$ & $\begin{array}{c}\text { V. 1940 } \\
\text { syntyneet \% }\end{array}$ & p-arvo \\
\hline Päivittäistoiminnot & & & \\
\hline Pystyy kävelemään puolen km matkan & 92 & 96 & $<0.001$ \\
Pystyy liikkumaan asunnossa & 99 & 100 & $<0.001$ \\
Pystyy nousemaan ylös tuolista tai sängystä & 98 & 100 & $<0.001$ \\
Pystyy kävelemään 1o porrasta ylös & 92 & 98 & $<0.001$ \\
Pystyy syömään itsenäisesti & 100 & 100 & 1.000 \\
Pystyy pukeutumaan itsenäisesti & 99 & 99 & 1.000 \\
Pystyy peseytymään itsenäisesti & 99 & 99 & $0.10 \mathrm{x}$ \\
Pystyy käyttämään WC:tä itsenäisesti & 100 & 100 & $0.25 \mathrm{x}$ \\
\hline Välineelliset toiminnot & & & \\
\hline Pystyy tekemään raskaita kotitöitä & 83 & 84 & $0.59 \mathrm{x}$ \\
Pystyy tekemään kevyitä kotitöitä & 98 & 99 & $0.05 \mathrm{x}$ \\
Pystyy tekemään henkilökohtaiset ostokset & 96 & 98 & $<0.001$ \\
Pystyy valmistamaan omat ateriat & 97 & 96 & $0.24 \mathrm{x}$ \\
Pystyy hoitamaan omat raha-asiat itsenäisesti & 98 & 99 & $0.30 \mathrm{x}$ \\
Pystyy käyttämään puhelinta & 99 & 100 & $0.55 \mathrm{x}$ \\
Pystyy kantamaan 5 kg taakan & 87 & 93 & $<0.001$
\end{tabular}

tyneistä joka viidennen painoindeksi oli yli $29 \mathrm{~kg} / \mathrm{m}^{2}(\mathrm{p}<0.001)$.

\section{Fyysinen toimintakyky}

Molemmissa kohorteissa suurin osa 70-vuotiaista selviytyi kaikista päivittäistoiminnoista (taulukko 4). Kohorttien välillä oli kuitenkin ero nuoremman kohortin eduksi 500 metrin kävelemisessä, asunnossa liikkumisessa, sängystä ja tuolista ylösnousemisessa ja 10 portaan nousemisessa (kaikissa p-arvo <0.001). Suurimmat erot kohorttien välillä olivat 10 portaan nousemisessa ja 500 metrin kävelemisessä. 
Taulukko 5. Vuonna $1920(n=1032)$ ja $1940(n=956)$ syntyneiden 70 -vuotiaiden toimintaa haittaavat oireet (\%).

\begin{tabular}{|c|c|c|c|}
\hline & $\begin{array}{c}\text { V. } 1920 \\
\text { syntyneet \% }\end{array}$ & $\begin{array}{c}\text { v. } 1940 \\
\text { syntyneet \% }\end{array}$ & p-arvo \\
\hline \multicolumn{4}{|c|}{ Pohjekipu kävellessä } \\
\hline $\mathrm{Ei}$ & 68 & 84 & \\
\hline Toisinaan & 22 & 13 & \\
\hline Päivittäin & 10 & 3 & $<0.001$ \\
\hline \multicolumn{4}{|c|}{ Toimintaa haittaava päänsärky } \\
\hline $\mathrm{Ei}$ & 81 & 91 & \\
\hline Toisinaan & 15 & 8 & \\
\hline Päivittäin & 4 & 1 & $<0.001$ \\
\hline \multicolumn{4}{|c|}{ Toimintaa haittaava huimaus } \\
\hline $\mathrm{Ei}$ & 77 & 86 & \\
\hline Toisinaan & 20 & 13 & \\
\hline Päivittäin & 3 & 1 & $<0.001$ \\
\hline \multicolumn{4}{|c|}{ Ruokahaluttomuus } \\
\hline $\mathrm{Ei}$ & 90 & 94 & \\
\hline Toisinaan & 8 & 5 & \\
\hline Päivittäin & 2 & 1 & $<0.001$ \\
\hline \multicolumn{4}{|c|}{ Rintakipuja levossa } \\
\hline $\mathrm{Ei}$ & 79 & 90 & \\
\hline Toisinaan & 19 & 9 & \\
\hline Päivittäin & 2 & 1 & $<0.001$ \\
\hline \multicolumn{4}{|c|}{ Rintakipuja rasituksessa } \\
\hline $\mathrm{Ei}$ & 70 & 88 & \\
\hline Toisinaan & 26 & 11 & \\
\hline Päivittäin & 4 & 1 & $<0.001$ \\
\hline \multicolumn{4}{|c|}{ Hengenahdistusta levossa } \\
\hline $\mathrm{Ei}$ & 88 & 93 & \\
\hline Toisinaan & 11 & 6 & \\
\hline Päivittäin & 1 & 1 & $<0.001$ \\
\hline \multicolumn{4}{|c|}{ Hengenahdistusta rasituksessa } \\
\hline $\mathrm{Ei}$ & 57 & 67 & \\
\hline Toisinaan & 33 & 30 & \\
\hline Päivittäin & 10 & 3 & $<0.001$ \\
\hline
\end{tabular}

Vuonna 1940 syntyneet kokivat selviytyvänsä paremmin kevyistä kotitöistä ( $\mathrm{p}=0.050)$, henkilökohtaisten ostosten tekemisestä $(\mathrm{p}<0.001)$ ja viiden kilon taakan kantamisesta $(\mathrm{p}<0.001)$ kuin vuonna 1920 syntyneet. Molemmissa kohorteissa eniten vaikeuksia koettiin raskaiden kotitöiden tekemisessä ja viiden kilon takan kantamisessa.
Toimintaa haittaavat oireet

Vuonna 1940 syntyneiden kohortissa oli 18 prosenttiyksikköä vähemmän niitä, jotka kokivat rasituksessa rintakipua ja 16 prosenttiyksikköä vähemmän rasituksen aikaisesta pohjekivusta kärsiviä kuin vuonna 1920 syntyneiden kohortissa (taulukko 5). Molemmissa kohorteissa vähiten toimintaa haittaavina oireina 
koettiin ruokahaluttomuutta ja hengen ahdistusta levossa. Eniten toimintaa haittaava oire oli hengenahdistus rasituksessa, jota koki vuonna 1920 syntyneiden kohortissa toisinaan tai päivittäin lähes joka toinen ja vuonna 1940 syntyneiden kohortissa joka kolmas vastanneista.

\section{Pohdinta}

Tutkimuksen tulosten mukaan vuonna 1940 syntyneestä kohortista koki itsensä terveeksi lähes joka viides, kun vuonna 1920 syntyneestä kohortista vain joka kymmenes koki itsensä terveeksi. Aikaisempien tutkimusten mukaan ikäihmisten koettu terveys on pääsääntöisesti parantunut vuosien saatossa (Leinonen ym. 2006; Galenkamp ym. 2012; Helldán \& Helakorpi 2014; Johansson, Midlöv \& Sundquist 2015). Tämän tutkimuksen tulokset tukevat aikaisempien tutkimusten havaintoja. Eläkeikäisen väestön terveyskäyttäytyminen ja terveys -tutkimuksen mukaan suomalaisten koettu terveys on parantunut tasaisesti 1990-luvun alusta alkaen (Helldán \& Helakorpi 2014). Hyväksi koettu terveys kuvaa hyvin ikääntyneiden kokonaisterveyden tilaa (Jylhä 2009; Ocampo 2010). Oman terveytensä hyväksi kokeminen vahvistaa yleisesti elämään tyytyväisyyttä (Eloranta ym. 2015) ja tukee ikäihmisten kotona selviytymistä (Brønum-Hansen ym. 2009).

Täysin raittiiden 70-vuotiaiden osuus oli pienentynyt 20 vuoden aikana. Alkoholin käytön määrää ei tässä tutkimuksessa selvitetty. Waddin ja Papadopoulosin (2014) tutkimuksen mukaan ikäihmisten alkoholin käytön määrä on pysytellyt melko samankaltaisena ajan saatossa. Perinteisen käsityksen mukaan alkoholin käyttö vähenee iän myötä, mutta kuva on muuttumassa (Sulander 2013). Tämän tutkimuksen tulokset vahvistavat tätä aikaisempaa havaintoa. Aikaisemmissa tutkimuksissa on myös viitteitä siitä, että alkoholin käytöstä seuraavat haitat saattavat ikääntyneil- lä kasvaa tulevaisuudessa ja lisätä sosiaali- ja terveydenhuollon palveluiden käyttöä (Wadd \& Papadopoulos 2014). Tulos vaatisi lisäselvityksiä. Tulevaisuudessa alkoholin käytön ja siihen liittyvien haittojen seurantaa tarvitaan, jotta kehityssuuntaa pystytään arvioimaan tarkemmin. Tieto auttaisi alkoholiin liittyvää poliittista päätöksentekoa sekä ennaltaehkäisevän palvelun kohdentamista.

Noin puolet 70-vuotiaista oli normaalipainoisia molemmissa kohorteissa, mutta ylipainoisten ikääntyneiden osuus oli kasvanut nuoremmassa kohortissa vanhempaan kohorttiin verrattuna. Vaikka ylipaino on yleensä terveysriski (Käypä hoito -suositus 2013), 70 vuotta täyttäneillä ylipaino ja joissakin sairauksissa jopa lievä lihavuus näyttäisivät suojaavan ennenaikaisen kuoleman riskiltä (Winter, MacInnis, Wattanapenpaiboon \& Nowson 2014). Havainto on tärkeä, ja tulevaisuudessa kliinisessä työssä ikäihmisten painon kehitystä tuleekin seurata. Terveyden ja toimintakyvyn säilymisen tueksi ikäihmisille tulee tarjota yksilöllistä ravitsemushoitoa, tukea ja mahdollisuuksia lihaskunnon ylläpitoon sekä pyrkiä ehkäisemään painonvaihteluita (Ravitsemussuositukset ikäihmisille 2010; Suominen, Soini, Muurinen, Strandberg \& Pitkälä 2012).

Suurin osa molempien kohorttien 70vuotiaista selviytyi päivittäistoiminnoista. Kohorttien välillä oli ero nuoremman kohortin eduksi erityisesti 10 portaan nousemisessa ja 500 metrin kävelemisessä. Nuorempi ikäkohortti koki myös selviytyvänsä paremmin kevyissä kotitöissä, ostoksien tekemisessä ja viiden kilon taakan kantamisessa vanhempaan kohorttiin verrattuna. Havaittu ero päivittäis- ja välinetoiminnoissa on kliinisen työn näkökulmasta hyvin pieni. Tulos kuitenkin vahvistaa aikaisempien tutkimusten tuloksia (Laitalainen ym. 2010; Martin ym. 2012; Helldán \& Helakorpi 2014; Morciano ym. 2015), joiden mukaan ikäihmisten toimintakyky oli parantunut ajan saatossa. Vanhuudesta johtuva toimintakyvyn heikentyminen näyt- 
tää alkavan nykyään myöhemmällä iällä kuin aiemmin (Laitalainen ym. 2010; Martin ym. 2012; Helldán \& Helakorpi 2014; Morciano ym. 2015). Ihmisten elinajanodote on kehittynyt suotuisaan suuntaan: vuonna 1940 syntyneiden elinajanodote 70-vuotiaana on viitisen vuotta pidempi kuin vuonna 1920 syntyneiden elinajanodote 70-vuotiaana (Rechel ym. 2013).

\section{Tutkimuksen luotettavuus}

Tutkimuksessa vertailtiin vuosina 1920 ja 1940 syntyneiden kotona asuvien 70-vuotiaiden koettua terveyttä, elintapoja ja fyysistä toimintakykyä. Terveen vanhenemisen teoria korostaa ihmisen itsearvioidun terveyden merkitystä (Heikkinen 2013). Lisäksi kotona asuvien ikäihmisten määrän lisääntyessä on päivittäisestä suoriutumisesta tullut kriittinen mittari kotona selviytymiselle (Valta 2008). Kaksi poikkileikkausaineistoa mahdollistivat terveyden ja toimintakyvyn vertailun kohorttien välillä. Aineiston keruun ajankohtien välillä oli 20 vuotta. Fyysisen toimintakyvyn mittarina käytetyt päivittäis- ja välinetoiminnot erottelevat huonosti ryhmiä, koska harvoilla oli näissä toiminnoissa ongelmia vielä 70-vuotiaana. Lisäksi päivittäis- ja välineellisten toimintojen väittämien vastausvaihtoehdot olivat hieman erilaiset TUVA- ja UTUVA-tutkimuksissa. Tästä johtuen TUVA-tutkimuksen vastausvaihtoehdot luokiteltiin uudelleen kyseisten muuttujien osalta. Tältä osin tutkimuksemme tuloksiin tulee suhtautua varauksella.

\section{Kirjallisuus}

Ahacic, K., Kennison, R. \& Thorslund, M. (2008). Trends in smoking in Sweden from 1968 to 2002: Age, period and cohort patterns. Preventive Medicine, 46(6), 558-564.

Angleman, S., Santoni, G., Von Strauss, E. \& Fratiglioni, L. (2015). Temporal Trends of Functional Dependence and Survival among Older Adults from 1991 to 2010 in Sweden: Toward a Healthier Aging. Journal of Gerontology: Medical Sciences 70(6), 746-752.
Otoksen sisäistä validiteettia paransivat tarkkaan määritelty tutkittavien ikä, vain kotona asuvat ja väestötason otanta. Tutkimuksen otos oli kattava (vastausprosentti noin 72), jolloin tulosten voidaan ajatella kuvaavan hyvin kotona asuvan 70-vuotiaan terveyttä, elintapoja ja fyysistä toimintakykyä. Tulokset olivat myös samansuuntaiset verrattuna muihin suomalaisiin ikääntyneiden terveyden, elintapojen ja fyysisen toimintakyvyn eroja arvioiviin kohorttitutkimuksiin.

\section{Johtopäätökset}

Näyttää siltä, että ikäihmisten koettu terveys ja fyysinen toimintakyky ovat kehittyneet suotuisaan suuntaan viime vuosikymmenten aikana. Tulokset antoivat viitteitä myös siitä, että vuonna 1940 syntyneet käyttivät useammin alkoholia ja olivat useammin ylipainoisia vuonna 1920 syntyneisiin verrattuna. Havainto on tärkeä. Tulevaisuudessa tarvitaan ikäihmisten alkoholin käytön ja painon kehityksen seurantaa, jotta pystytään tarkemmin arvioimaan kehityssuuntausta ja sen vaikutuksia ikäihmisten terveydelle ja hyvinvoinnille.

\section{Yhteydenotto:}

Sini Eloranta, sh, TtT, hoitotieteen dosentti, lehtori Turun ammattikorkeakoulu (Terveys ja hyvinvointi), Turun yliopisto (Hoitotieteen laitos)

Sähköposti: sinelo@utu.fi

Arve, S., Eloranta, S., Rovio, S., Isoaho, H., Viitanen, M. \& Lehtonen, A. (2012). Depressive symptoms among older people: a 15-year follow-up. Aging Clinical and Experimental Research 24(5), 501-508.

Brønum-Hanssen, H., Petersen, I., Jeune, B. \& Christensen K. (2009). Lifetime according to health status among oldest old in Denmark. Age and Ageing 38(1), 47-51. 
Cabrera, C.,Wilhelmson, K., Allebeck, P., Wedel, H., Steen, B. \& Lissner, L. (2003). Cohort differences in obesity-related health indicators among 70year olds with special references to gender and education. European Journal of Epidemiology 18(9), 883-890.

De Munter, J., Tynelius, P., Magnusson, C. \& Rasmussen, F. (2015). Longitudinal analysis of lifestyle habits in relation to body mass index, onset of overweight and obesity: Results from a large population-based cohort in Sweden. Scandinavian Journal of Public Health 43(3), 236-245.

Dey, D.K., Rothenberg, E., Sundh, V., Bosaeus, I. \& Steen, B. (2001). Height and Body Weight in Elderly Adults: A 21-Year Population Study on Secular Trends and Related Factors in 70-YearOlds. Journals of Gerontology Series A: Biological Sciences and Medical Sciences 56(12), 780-784.

Donald, I., Foy, C. \& Jagger, C. (2010). Trends in disability prevalence over 10 years in older people living in Gloucestershire. Age and Ageing 39, 337-342.

Eloranta, S., Arve, S., Isoaho, H., Lehtonen, A. \& Viitanen, M. (2015). Loneliness of older people aged 70: a comparison of two Finnish cohorts born 20 years apart. Archives of Gerontology and Geriatrics 61(2), 254-260.

Espelt, A., Font-Ribera, L., Rodriguez-Sanz, M., Artazcoz, L., Ferrando, J., Plaza, A. \& Borell, C. (2010). Disability among Older People in a Southern European City in 2006: Trends in Gender and Socioeconomic Inequalities. Journal of Women's Health 19(5), 927-933.

Falk, H., Johansson, L., Östling, S., Thøgersen Agerholm, K., Staus, M., Høst Dørfinger, L. \& Skoog, I. (2014). Functional disability and ability 75-year-olds: a comparison of two Swedish cohorts born 30 years apart. Age and Ageing 43(5), 636-641.

Galenkamp, H., Braam, A., Huisman, M. \& Deeg, D.J. (2012). Seventeen-year time trend in poor self-rated health in older adults: changing contributions of chronic diseases and disability. European Journal of Public Health 23(3), 511-517.

Giron, P. (2016). Time Trends in Self-Rated Health and Disability in Older Spanish People: Differences by Gender and Age. Iranian Journal of Public Health 45(3), 289-296.

Grove, S.K., Burns, N. \& Gray, J.R. (2013). The Practice of Nursing Research; Appraisal, Synthesis, and Generation of Evidence. 7th edition. Philadelphia: W.B. Saunders.

Heeb, J-L. (2009). Changes in the prevalence of overweight and obesity: some evidence from the Swiss Health Surveys 1992/93 and 2002. European Journal of Public Health 21(4), 407-413.

Heikkinen, E. (2013). Terveyden arviointi. Gerontologia 27(4), 397-405.

Helldán, A. \& Helakorpi, S. (2014). Eläkeikäisen väestön terveyskäyttäytyminen ja terveys keväällä 2013 ja niiden muutokset 1993-2013. Tampere: Terveyden ja hyvinvoinnin laitoksen raportteja 15, Terveyden ja hyvinvoinnin laitos.

Jagger, C., Matthews, R., Matthews, F., Spiers N.A., Nickson, J., Paykel, E.S., Huppert, F. \& Brayne, C. (2007). Cohort differences in disease and disability in the young-old: findings from the MRC Cognitive Function and Ageing Study (MRCCFAS). BMC Public Health 7, 156-163.

Jiménez Trujillo, I., Jiménez García, R., Vazquez-Fernandez del Prozo, S., Hernández Barrera, V., Carrasco Garrido, P. \& Gil de Miquel A. (2010). Trends from 1995 to 2006 in the prevalence of self-reported cardiovascular risk factors among elderly Spanish diabetics. Diabetes $\xi^{\circ}$ Metabolism 36(1), 29-35.

Johansson, S-E., Midlöv, P. \& Sundquist, J. (2015). Longitudinal trends in good self-rated health: effects of age and birth cohort in a 25-year follow-up study in Sweden. International Journal of Public Health 60(3), 363-373.

Jylhä, M., Vuorisalmi, M., Luukkaala, T., Sarkeala, T. \& Hervonen, A. (2009). Elinikä pitenee nopeammin kuin toimintakyky paranee. 90-vuotiaiden ja sitä vanhempien toimintakyvyn muutokset vuosina 1996-2007. Suomen Lääkärilebti 25, 2285-2290.

Karadag Caman, O., Calling, S., Midlöv, P., Sundqvist J., Sundqvist K. \& Johansson, S-E. (2013). Longitudinal age-and cohort trends in body mass index in Sweden - a 24-year follow-up study. BMC Public Health 13, 893-902.

Katz, S. (1983). Assessing self-maintenance: Activities of daily living, mobility and instrumental activities of daily living. Journal of the American Geriatrics Society 31(12), 721-726.

Kumar Dey, D., Rothenberg, E., Sundh, V., Bosaeus, I. \& Steen, B. (2001). Height and Body Weight in Elderly Adults: A 21-Year Population Study on 
Secular Trends and Related Factors in 70-YearOlds. Journal of Gerontology 56(12), 780-784.

Käypä hoito -suositus (2013). Lihavuus (aikuiset). Suomalaisen Lääkäriseuran Duodecimin ja Suomen Lihavuustutkijat ry:n asettama työryhmä. Helsinki: Suomalainen Lääkäriseura Duodecim. Haettu 24.11.2017 osoitteesta: www.kaypahoito.fi

Lahelma, E. (2012). Eriarvoisuus vanhuudessa ja terveydessä. Teoksessa Kohti parempaa vanhuutta. Konsensus-kokous 2012 (s. 34-43). Suomalainen Lääkäriseura Duodecim, Suomen Akatemia.

Laitalainen, E., Helakorpi, S., Martelin, T. \& Uutela, A. (2010). Eläkeikäisten toimintakyky on parantunut, mutta ei kaikissa väestöryhmissä. Suomen Lääkärilehti 65, 3295-3301.

Lehtonen, A. \& Tilvis, R. (1994). Turun vanhustutkimus. Turkulaisten 70 -vuotiaiden terveydentila, toimintakyky ja terveyspalvelujen tarve. Turku: Turun kaupungin terveydenhuollon julkaisuja n:o 10.

Leinonen, R., Suominen, V., Sakari-Rantala, R., Laukkanen, P. \& Heikkinen, E. (2006). Terveydentila ja päivittäisistä toiminnoista selviytyminen 65-69 -vuotiailla jyväskyläläisillä vuosina 1988, 1996 ja 2004. Teoksessa Heikkinen, E., Kauppinen, M., Salo, P-L. \& Suutama, T. (toim.), Ovatko 65-69-vuotiaat aikaisempaa toimintakykyisempiä, terveempiä ja aktiivisempia? Havaintoja Ikivihreät-projektin kohorttivertailututkimuksesta vuosilta 1988, 1996 ja 2004 (s. 43-66). Kela: Sosiaali- ja terveysturvan tutkimuksia 83.

Leskinen, R., Laatikainen, T., Tuomilehto, J., Nissinen, A., Peltonen, M. \& Antikainen, R. (2010). Trends in health status and the use of services among the 80-84-year-old Finnish war veterans during 1992 and 2004. Scandinavian Journal of Public Health 38, 434-441.

Martin, L., Schoeni, R., Andreski, P. \& Jagger, C. (2012). Trends and inequalities in late-life health and functioning in England. Journal of Epidemiology and Community Health 66(10), 874-880.

Martinez-Huedo, M.A, Lopez de Andres, A., Hernandez-Barrera, V., Palacios-Cena, D., Hernandez, D.M. \& Jiménez-Garcia, R. (2011). Trends in the prevalence of physical and functional disability among Spanish elderly suffering from diabetes (2000-2007). Diabetes Research and Clinical Practice 94(2), 30-33.
Morciano, M., Hancock, R. \& Pudney, S. (2015). Birth-cohort trends in older-age functional disability and their relationship with socio-economic status: Evidence from a pooling of repeating cross-sectional population-based studies for the UK. Social Science \& Medicine 1-9, 2015.

Ocampo,J.M. (2010). Self-rated health: Importance of use in elderly adults. Colombia Medicine 41(3), 275-289.

Palacios-Ceña, D., Jiménez-Garcia, R., Hernández-Barrera, V., Alonso-Blanco, C., Carrasco-Garrido, P. \& Fernandez-de-Las-Penas, C. (2012). Has the Prevalence of Disability Increased Over the Past Decade (2000-2007) in Elderly People? A Spanish Population-based Survey. Journal of American Medical Directors Association 13(2), 136-142.

Parker, M., Ahacic, K. \& Thorslund, M. (2005). Health Changes among Swedish Oldest Old: Prevalence Rates From 1992 and 2002 Show Increasing Health Problems. Journal of Gerontology 60(10), 1351-1355.

Pérés, K., Helmer, C., Letenneur, L.,Jacqmin-Gadda, H. \& Barberger-Gateau, P. (2005). Ten-year change in disability prevalence and related factors in two generations of French elderly community dwellers: data from the PAQUID study. Aging Clinical and Experimental Research 17(3), 229-235.

Ravitsemussuositukset ikääntyneille (2010). Valtion ravitsemusneuvottelukunta. Helsinki: Edita Prima Oy. Haettu 24.11.2017 osoitteesta: http:// www.ravitsemusneuvottelukunta.fi/attachments/ vrn/ikaantyneet.suositus.pdf

Rechel, B., Grundy, E., Robine, J-M., Cylus, J., Mackenbach, J.P., Knai, C. \& Mckee, M. (2013). Ageing in the European Union. Lancet 381, 312 1322.

Sjölund, B.M., Wimo, A., Qiu, C., Engström, M. \& von Strauss, E. (2014). Time trends in prevalence of activities of daily living (ADL) disability and survival: Comparing two populations (aged 78+ years) living in a rural area in Sweden. Archives of Gerontology and Geriatrics 58(3), 370-375.

Steen, B. (2002). The elderly yesterday, today and tomorrow: aspects on cohort differences from the gerontological and geriatric population studies in Goteborg, Sweden (H70). Archives of Gerontology and Geriatrics 8, 359-70. 
Sulander, T. (2013). Elintavat ja toimintakyvyn moniulotteisuus terveyden ennustajina. Suosituksia interventioiden ja tukiohjelmien tueksi. Sosiaalitieteiden laitoksen julkaisuja 2013:6 Yhteiskuntapolitiikka. Helsinki: Helda.

Suominen, M., Soini, H., Muurinen, S., Strandberg, T. \& Pitkälä, K. (2012). Ikääntyneiden ruokatottumukset, ravinnonsaanti ja ravitsemustila suomalaisissa tutkimuksissa. Sosiaalilääketieteellinen aikakauslehti 49, 170-179.

TENK = Tutkimuseettinen neuvottelukunta (2012). Hyvä tieteellinen käytäntö ja sen loukkausepäilyjen käsitteleminen Suomessa. Helsinki: Tutkimuseettinen neuvottelukunta.

Tilastokeskus 2016. Väestöennuste. Haettu 24.11.2017 osoitteesta: http://www.stat.fi/til/ vaenn/2015/vaenn_2015_2015-10-30_tie_001_ fi.html

van Gool, C.H., Picavet, H.S., Deeg D.J., de Klerk M.M., Nusselder, W.J., van Boxtel, M.P., Wong, A. \& Hoeymans, N. (2011). Trends in activity limitations: the Dutch older population between 1990 and 2007. International Journal of Epidemiology 40(4), 1056-1067.
Valta, A. (2008). Iäkkäiden päivittäinen suoriutuminen kotona. Teoreettinen malli iäkkäiden kotona asuvien päivittäisestä suoriutumisesta kotisairaanhoitajien ja iäkkäiden näkökulmasta. Väitöskirja. Tampere: Acta Electronica Universitatis Tamperensis, 789.

Wadd, S. \& Papadopoulos, C. (2014). Drinking behavior and alcohol-related harm amongst older adults: analysis of exiting UK datasets. BMC Research Notes 20(7), 741-749.

Whitley, E., Popham, F. \& Benzeval, M. (2016). Comparison of the Rowe-Kahn Model of Successful Aging With Self-rated Health and Life Satisfaction: The West of Scotland Twenty-07 Prospective Cohort Study. Gerontologist 56(6), 1082-1092.

WHO, World Health Organisation. (2016). World Health Statistics 2016: Monitoring health for the SDGs, 2016. Haettu 24.11.2017 osoitteesta: http://www.who.int/gho/publications/world_ health_statistics/2016/en/

Winter, J., MacInnis, R., Wattanapenpaiboon, N. \& Nowson, C.A. (2014) BMI and all-cause mortality in older adults: a meta-analysis. American Journal of Clinical Nutrition 99(4), 875-890. 